ppi $201502 Z U 4645$

Esta publicación científica en formato digital es continuidad de la revista impresa ISSN-Versión Impresa 0798-1406 / ISSN-Versión on line 2542-3185Depósito legal pp $197402 Z$ U34
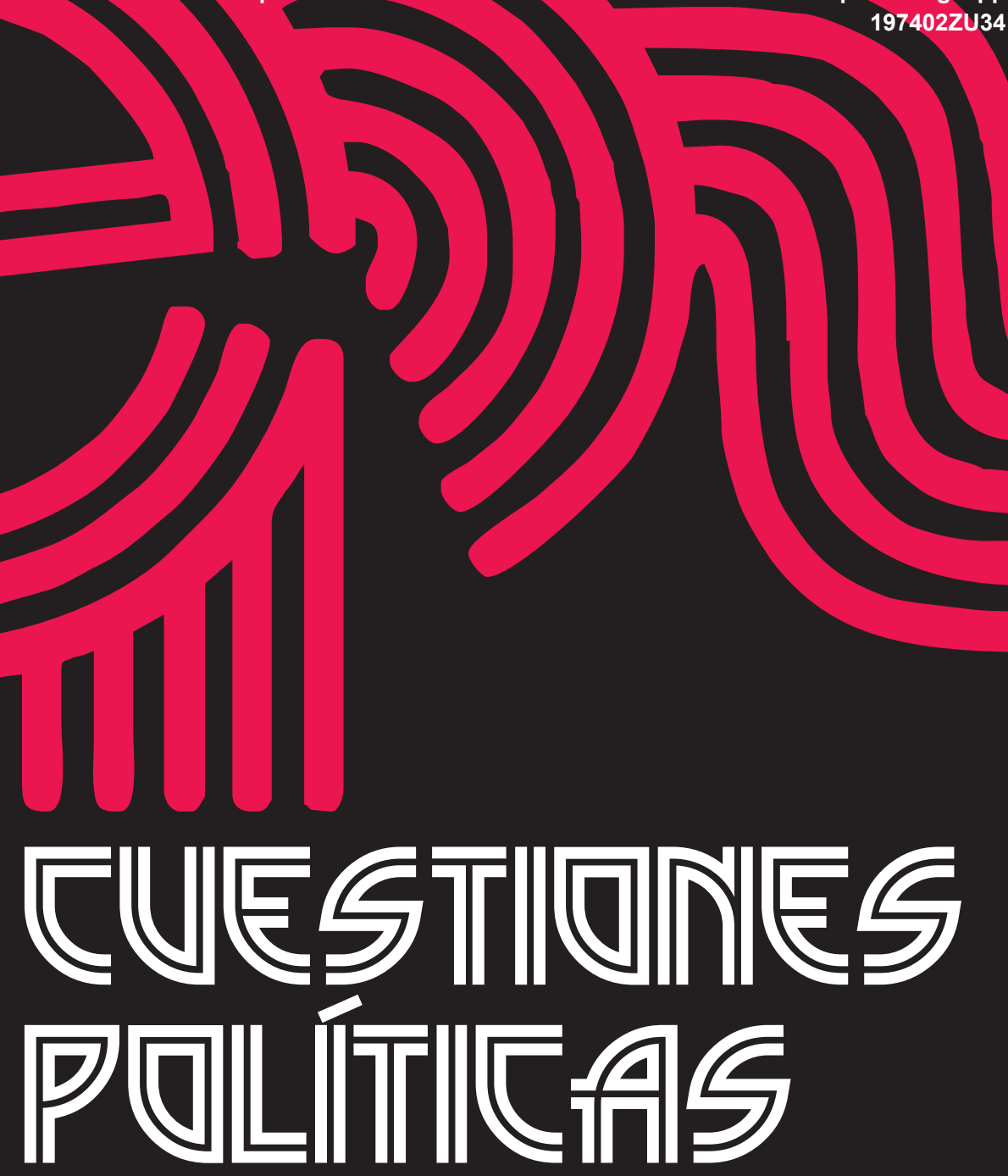

Instituto de Estudios Políticos y Derecho Público "Dr. Humberto J. La Roche" de la Facultad de Ciencias Jurídicas y Políticas de la Universidad del Zulia Maracaibo, Venezuela
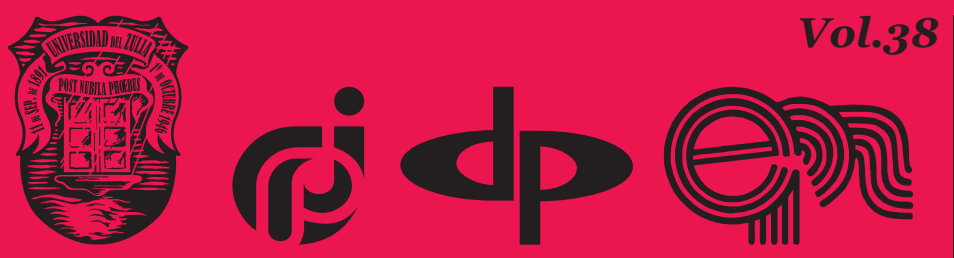

$N^{\circ}$ Especial 2da Parte 2020 


\title{
Foreign experience in professional development of private detectives
}

\author{
DOI: https://doi.org/10.46398/cuestpol.382e.40
}

\author{
Denysiuk Stanislav * \\ Motyl Ivan ** \\ Vartyletska Inna *** \\ Symonenko Nataliia \\ Korotaiev Volodymyr *****
}

\section{Abstract}

The objective of the article is to analyze international experience in the professional development of private detectives, in order to implement some positive aspects in Ukrainian law. The methodological basis of the research was articulated in a set of general and special scientific methods of scientific knowledge, a saber: historical comparative method and legal method, dialectic, induction method, comparative and legal method, formal and legal method. Based on the analysis of international experience, the education problems of private detectives, as well as those that recycling and advanced training features, whose study is necessary for the full development of the institution of the activity of private detectives in Ukraine, reveals the revelation of modern services for the training of private detectives in Ukraine. In the conclusions, the authors pay special attention to specialists in the activity of private detectives in several countries, where private detectives have a wide range of opportunities and their activity is actually compared to the activity of law enforcement. Finally, the requirements are proposed for candidates for the position of private detective, as well as for the program of their training.

Keywords: private detective; private detective training program; comparative studies; problems of detective practice; Ukraine.

Doctor of Law, Professor, Chief researcher of the Scientific Institute of Public Law. ORCID ID: https:// orcid.org/o0oo-0002-5296-0519. Email: siplasl2019@gmail.com

** PhD in Law, Director of the Educational and Scientific Institute of Correspondence and Distance learning of the National Academy of Internal Affairs. ORCID ID: https://orcid.org/oooo-0002-83368630. Email: nnizn@naiau.kiev.ua

*** PhD in Law, Associate Professor, Professor of Criminal Law Department of the National Academy of Internal Affairs. ORCID ID: https://orcid.org/oooo-0002-3447-0567. Email: kkpnavs@ukr.net

**** PhD in Law, Associate Professor of Criminal Law Department of National Academy of Internal Affairs. ORCID ID: https://orcid.org/oooo-0oo3-1048-278X.Email: natalka_88@ukr.net

*****PhD in Law, Director of Dnipropetrovsk Research Forensics Center of the Ministry of Internal Affairs of Ukraine. ORCID ID: https://orcid.org/oooo-0o02-0269-0389. Email: ndekc_dnepr@ukr.net 


\section{Experiencia internacional en la formación de detectives privados}

\section{Resumen}

El objetivo del artículo es analizar la experiencia internacional en el desarrollo profesional de detectives privados, con el fin de implementar algunos aspectos positivos en la legislación de Ucrania. La base metodológica de la investigación se articuló en un conjunto de métodos científicos generales y especiales de conocimiento científico, a saber: método comparativo histórico y legal, método dialéctico, método de inducción, método comparativo y legal, método formal y legal (dogmático). Sobre la base del análisis de la experiencia internacional, los problemas de educación de los detectives privados, así como las características de su reciclaje y formación avanzada, cuyo estudio es necesario para el pleno desarrollo de la institución de la actividad de detectives privados en Ucrania, se revela la esencia de los enfoques modernos para la formación de detectives privados en Ucrania. En las conclusiones los autores prestan especial atención a las peculiaridades de la actividad de los detectives privados en varios países, donde los detectives privados tienen una amplia gama de oportunidades y su actividad se compara en realidad a la actividad de las fuerzas del orden. Finalmente, se proponen los requisitos para los candidatos al cargo de detective privado, así como para el programa de su formación.

Palabras clave: detective privado; programa de formación de detectives privados; estudios comparativos; problemas de la práctica de detectives; Ucrania.

\section{Introduction}

In developed democracies (Germany, France, Great Britain, USA, etc.), the system of training of private detectives has been formed since the $50 \mathrm{~s}$ of the $2 \mathrm{O}^{\text {th }}$ century. This system includes educational programs for training specialists in the following specialties: "Security management" (educational levels: bachelor, master), "Private Detective" (qualification level: bachelor), "Bodyguard' (working profession), "Security guard" (working profession).

There was a tendency to introduce a number of specializations in the working profession "Security guard" (security guard for tours, security guard for educational institutions, security guard for police stations, security guard for convoying property on railway transport, air transport, security guard for megamarkets, etc.) in the European countries at the beginning of the $21^{\text {st }}$ century; so there are 5 such specializations in Germany there are 5, 
and 17 - in Israel. Training programmes and system of training or advanced training are developed under each specialization. Involvement of law enforcement professionals in the development of security and protection training systems for the private security sector and their certification is the indispensable condition for European countries and the United States (Kobeletskyi, 2013).

Since private detective activity is not a hobby but a professional activity, it is common practice in modern countries to create special educational institutions for training and retraining of private detectives. As a rule, parttime and external studies are not allowed. (Musienko, 1996) notes that there are 14 private search colleges, which prepare specialists with a bachelor's degree and 5 colleges, which prepare specialists with a master's degree in private search in the USA. Obviously, such a systematic approach to ensuring national security is relevant for the current situation in Ukraine. Trainings in the specialty of "Security management" are carried out in many European countries and the United States. Security management professionals are engaged in different posts from private detective to security manager in these countries. The training of specialists in European countries in the field of national security has, first of all, a practical orientation.

Taking into account that private detective activity in Ukraine is at the stage of formation nowadays, the world experience should be taken as a basis. So, let us consider the experience of some countries in the training, preparation and retraining of private detectives.

The aim of our study is to provide the analysis of the procedure of training, retraining and advanced training of private detectives in some foreign countries in order to study positive experience and further implement it into Ukrainian legislation in this area.

\section{Materials and Methods}

The methodological basis of scientific research is a set of general scientific and special methods of scientific knowledge, specific to legal science.

Dialectical method is a general and universal method of forming legal concepts. It provides necessary and important stages of ascent from the abstract to the concrete, and from the concrete to the abstract. The application of the method of ascent from the abstract to the concrete is especially relevant when developing legal scientific theories and concepts. This method was important and necessary for examining the institution of professional development of private detectives as a holistic legal phenomenon and formulating key concepts related to this institution, to clarify the structure and features of the latter. 
The main problem to be solved with the help of historical and legal comparative method is to obtain new knowledge through comparisons of historical and legal sources. As one can see, this requires three components: 1) comparison (in some cases also an analogy), which is a standard general logical operation; 2) comparisons should be characterized by their retrospectiveness, i.e. be historical; 3) the legal matters should be compared. Only the combination of these three conditions is the content of the main problem of the theory of historical and legal comparative method and makes appropriate demands on the basic approaches and principles of its implementation. Historical and legal comperative method helped to study the genesis of the normative model of professional development of private detectives under the laws of different countries.

The method of induction is a method of cognition based on a formal and logical mental conclusion, which makes it possible to obtain a general conclusion based on the analysis of individual facts. It helped to analyze the problems related to the institution of preparation of private detectives in Ukraine based on the conducted reseach as well as to to draw some general conclusions.

In a general sense, comparative and legal method is a method of studying the legal phenomens of different States by comparing the same legal norms, institutions, principles, etc. and the practice of their application. Comparative and legal method was helpful in comparing the procedure for the preparation of private detectives in different countries, as well as the requirements for the candidates for the office of private detectives.

Formal and legal (or dogmatic) method involves the study of legal facts and legal texts, their interpretation in a logical sequence using special legal terms and constructions. By applying this method, we could examine the context of the legal acts, which regulate the issue of professional development of private detectives in some countries of the world.

\section{Literature review}

The features of private detective activities in separate countries were investigated by many foreign and domestic scientists. For example, Matiukhina's monograph "British Police: Current Trends in Development and Management" (2001) is devoted to current problems of the British police, as well as the main trends and approaches that determine its structure and development. Her second monograph "The US private security sector: the ways of development and realities of today" (2013) deals with the formation of non-governmental detective and security activities in the United States, and also includes some views of the author on the general trends in law enforcement in the modern world. 
Sachavo (2006) conducts in his scientific work "Administrative and legal framework of private security agencies and their interaction with the police of Ukraine" comparative and legal analysis of the development of private security activities in foreign countries (France, USA, Japan, Germany, etc.) and highlights their role in crime prevention.

Kyslyi and others (2020) investigated the features of professional development of private detectives in Ukraine based on the examination of the laws and draft laws, which were adopted at different historical stages in order to regulate the relations in this area.

Thus, the aim of our study is to provide the analysis of the procedure of professional development of private detectives in some foreign countries in order to study positive experience and further implement it into Ukrainian legislation in this area.

\section{Results and Discussion}

Local law of some States provides for certain additional requirements for those who have the right to be engaged in private detective activities. For example, to obtain a license of detective in California, one must have at least 6,000 hours of practical experience in investigations (i.e., 750 working days); but if one have obtained a degree in Law, it is sufficient to have 2,00o hours of relevant work. Besides, this State requires two exams: on knowledge of US law and English language exam (Bezzub, 2017).

Under the UK Police Reform Act (Act of the Parliament of the United Kingdom, 2002), detectives can be persons with at least two years of experience as a police officer, receive special training and pass exams. Criminal Investigation Departments (CID) are created at territorial police agencies and are engaged in investigation of serious crimes (murders, rapes, crimes connected with drug trafficking, organized crime, etc.). Special departments, which are specialized in the investigation of certain categories of serious crimes, can be formed as part of detective services departments.

The procedure for admission to the British police service is radically different from such procedure in Ukraine. The system of British police education can be rather called police training than police education, because practical training, internship, and practice play a significant role in the education. Matyukhina (2001) notes that all recruits undergo a 15-week training course in training centers (for the Metropolitan Police - 18 weeks) after admission to the service, where they acquire skills of police practice. The graduates of these courses must undergo a two-year probationary period in one of the police units in uniform under the supervision of an appointed mentor, after which they are awarded the title of constable. 
It was not until 2001 that a law was passed that introduced compulsory licensing of private detective activities and, consequently, registration of private detectives. With the adoption of this law, a special body - the British Safety Industry Federation - was created to carry out licensing and inspection of private detective activities. Belonging to a professional association, such as the British Detectives Association (ABS) or membership in such association, ensures that a person has sufficient experience in this area. You can become a member of the ABS by providing recommendations from government agencies (police, criminal or international investigation) and subject to availability of legal education (Official web-site of the Association of British Investigators, 2020).

In order to become a detective in Germany, a person does not need legal education or experience in law enforcement, because there are appropriate centers for the training of detectives in the country. For example, there is a Center for Detective Business Training, where future detectives are trained in criminology, law, economics, etc. Individuals receive training in such institutions (thtough direct or distance learning) in the area of criminology, law, economics, etc. Such training of future detectives usually takes place on weekends and lasts from one to two years. In Germany, private detective organizations and public law enforcement agencies work closely together in conducting special operations, sharing operational forces, tools, and exchanging information in training (Bezzub, 2017).

French law also has its own characteristics that distinguish it from English and German one: in France, private detectives are clearly separated from lawyers, attorneys, police officers and any other professions that are essentially close to the detective profession. French lawmakers subdivide private detective activity into search and security ones.

Training of private detectives was not mandatory in France until March 18,2003 , but it became mandatory after adopting relevant amendments to the legislation. The Pantheon University in Paris has been offering a twoyear detective training program with a State diploma since 2006. Detectives in France do not have the right to carry firearms.

To become a detective in France, the candidate must be 21 years old, be a citizen of France or another EU Member State, take a compulsory course at an educational institution determined by the French Ministry of the Internal Affairs (currently it is the Panthéon-Assas University Paris II), has not worked in the police, intelligence agencies, domestic security agencies or military formations for the last five years did not work; has no criminal record for committing a criminal offense; has no administrative or other disciplinary sanctions or be under investigation (Bezzub, 2017).

There are clear legal boundaries for the existence and operation of private security organizations In Finland. Opening of private search offices 
requires the permission of the relevant authorities. If the activity of a private security company is carried out on the territory of one province (region), such permission is issued by the governor, if simultaneously in several provinces - by the government. The legislation of Finland also defines general and mandatory requirements for employees of private security organizations: the presence of police or legal education, experience in local law enforcement agencies, high moral qualities and reliability (Kalenyak, 2007).

Private detective activity in Spain is separated from private security activity. Private detective cannot be engaged in activities performed by private security agencies, and vice versa.

The diplomas conferring the right to perform private detective activities are issued by universities and other educational institutions, which are determined by the Spanish Ministry of the Internal Affairs. Such educational institutions are: the University of Security and Science in Valencia, the Institute of Criminology in Barcelona, the Institute of Criminology in Madrid, the Institute of Criminology in Alicante, the College of San Pablo, the Salamanca University of Security Training (La Asociación Profesional de Detectives Privados de España, 2010).

Under the relevant law of the Republic of Slovenia, a license may be issued to an applicant who: is a citizen of the Republic of Slovenia or a Member State of the European Union, the European Economic Area or the Swiss Confederation; acquired a qualification after completing the first level of a professional training program or a similar qualification abroad, which is recognized in accordance with current national legislation governing this area of education; passed the exam in the specialty of detective; passed a special test; has not worked as a police officer or intelligence agency official for the past two years (Volynska, 2016).

The relevant educational activities in the Russian Federation are regulated at the legislative level. The Law of the Russian Federation "On Private Detective and Security Activities in the Russian Federation" stipulates that professional training for private detectives is performed in organizations engaged in educational activities under basic vocational training programs and additional professional programs except for parttime and external forms. The Ministry of Internal Affairs of the Russian Federation developed standard programs for professional training of private detectives (Order of the Federal service of the troops of the National Guard of the Russian Federation, 2019).

The Law of the Republic of Moldova "On Private Detective and Security Activities" (Law of the Republic of Moldova, 2003) of July 4, 2003 provides that only citizens of the Republic of Moldova, who have legal education or received special training in this area can be engaged in private detective 
activity. Admission to private detective activity of persons under 21 is prohibited; held liable for systematic violation of public order, drug use or convicted of an intentional crime; not certified in the prescribed manner for detective work; prosecuted. There are no requirements for the length of service, as well as many other well-founded requirements, which are in a similar law of the Russian Federation. Therefore, in this regard, the relevant provisions of Russian law should be considered more specific, complete and thoughtful (Yurko, 2017).

The practice of regularly informing private detectives about new trends and methods of combating crime has been introduced in Austria. Private security and detective agencies participate in the permanent meeting on crime prevention of the Ministry of Internal Affairs of the UK and have a permanent mission to it. The police provide assistance in the regular training, retraining, and advanced training of private detectives in Germany, Sweden, Greece and Turkey (Pidyukov, 2016).

The study allows us to obtain some results and generalizations:

1. Qualifications for education and special training, etc. are set for private detectives.

2. There are separate programs for the training of private detectives in educational institutions. In some cases, such training is conducted by special schools or centers (Bugaychuk, 2016).

Therefore, analyzed the experience of different countries in training of private detectives, it is necessary to consider the proposals for training, retraining and advanced training of private detectives in Ukraine.

Private detective courses in Ukraine are offered by the Training Group "SWORD". The training period is 7 days. General information about Private Detective Courses are based on cooperation with organizations specializing in training in the field of non-state security; the trainers are the experts of Training Group "SWORD" and specialists of organizations specializing in training in the area of non-state security. Preparation of groups "A", "B" and "C" on the full program of training or retraining are united in the general group; the certificate of the Training Group "SWORD" or the organization specializing in training in the area of non-state security is issued after attending the program. The program of training of private detectives provides studying of a wide range of theoretical issues and practical exercises, namely: in-depth legal training; technical training; psychological training; marketing in the field of private detective activity; economic training; practical classes on solving tasks in the provision of services in the area of private search.

In addition to various agencies and non-governmental organizations, the training and education of private detectives is also offered by private educational institutions. 
For example, the university "KROK" offers training to obtain educational and qualification level "specialist". The term of study is 2 years. Those who successfully complete the training will receive a State diploma. During the training one is given the opportunity to simultaneously work as a private detective, assistant private detective in private detective companies.

The Interregional Academy of Personnel Management offers a list of basic disciplines such as: "Criminal law aspects of private detective activity", "Forensic law enforcement", "Private Detective Activity and Detective Agencies" during the first (bachelor's) level of higher education. The main task of the course is to highlight the links between forensics and the activities of private detectives and the legal theoretical basis of forensics, which is the basis for systematic study of crime and its manifestations. Taking into account the general part of criminological science (the doctrine of crime and its patterns, criminogenic determinants, the identity of the perpetrator and the prevention of criminal activity), the fight against the most common categories of crimes in business for higher education institutions.

The program of the course "Private Detective Activity and Detective Agencies" is prepared taking into account the typical programs for higher education institutions. It provides coverage of the main provisions of science on the judiciary and the activities of private detectives and integrated approaches to the organization of the fight against crime, as well as direct connection with the activities of private detectives. Special attention is paid to the discussion of issues of practical implementation of prevention policy in Ukraine.

Zaporizhzhia National Technical University approved an educational program "Security activities" for students in the field of training "Physical culture and sports one of the disciplines". Comparing the courses, it is clear that training, preparation and retraining in private universities provides more effective acquisition of relevant skills, but the courses offered of private schools are not sufficient enough for the work of private detective.

Special training of private detectives is carried out by state and nonstate educational institutions according to the programs agreed with the Ministry of Internal Affairs of Ukraine, the Ministry of Health, and the Ministry of Finance of Ukraine.

That is why training programs for future private detectives should provide in-depth study of relevant legal disciplines and special courses, especially in Constitutional Law, Criminal and Administrative Law and Procedure, Criminology, special equipment, operational and investigative activities, tactical, medical, special weapon and physical trainings.

Such programs should be developed only by scientific and pedagogical staff with a sufficient professional level in the outlined areas on the basis of the experience of higher law schools with specific training conditions, the 
most powerful among which is the system of higher education institutions of the Ministry of Internal Affairs of Ukraine.

The introduction of the discipline of choice "Legal support and organization of private detective work" for students of the Faculty of Law at Dnepropetrovsk State University of Internal Affairs is also worth attention.

The discipline «Legal support and organization of private detective work» is a special selective course in the professional training system for students in the area of «Law Enforcement» at the Dnipropetrovsk State University of Internal Affairs. The course is based on separate sections of such disciplines as "Constitutional Law", "Judicial and Law Enforcement Agencies", "Investigative and Search Activities", "Criminal Law", "Criminal Procedure", "Forensics", "Administrative Law", "Special equipment in law enforcement ", etc.

This also applies to other special training courses and disciplines (special tactical training, use of special equipment and special technique, etc.). The legislation provides for the mandatory participation of the Minister of Internal Affairs of Ukraine and the National Police of Ukraine along with the Ministry of Education and Science of Ukraine in the development of training programs (special training, retraining and advanced training) for private detectives.

The above, in our opinion, convincingly testifies to the expediency of training private detectives in the system of universities of the Ministry of Internal Affairs of Ukraine with specific training conditions. The exemplary model of this system has always been and remains the National Academy of Internal Affairs, which has sufficient scientific and pedagogical potential, a strong educational base, the latest teaching methods, including special disciplines, as well as many years of experience in training (retraining and advanced training) for the Ministry of Internal affairs and the National Police of Ukraine, law enforcement agencies of foreign countries, the penitentiary service, as well as the National Mediation and Reconciliation Service, the State Anti-Corruption Service of Ukraine, UN peacekeeping missions and other government agencies.

Special training for private detectives is a kind of professional specialization for persons who already have higher legal education, but do not have three years of practical experience in the pre-trial investigation or operational units.

That is, the legislator aims to compensate for the gaps in the professional level of the candidate for private detectives, to form the skills inherent in former law enforcement officers by providing special training (specialization).

So, given the above, we consider the entire preparatory process of private detectives to be divided into three types: 
Denysiuk Stanislav, Motyl Ivan, Vartyletska Inna, Symonenko Nataliia y Korotaiev Volodymyr Foreign experience in professional development of private detectives

1. basic training - obtaining basic skills (driving a car, apprehending criminals, etc.).

2. Specialized training - additional training in various areas of law enforcement (criminal investigation, work with minors, negotiation, etc.).

3. Staff training - series of trainings for private detectives who are responsible for the work of other employees (Pavlenko et al., 2017).

Therefore, the purpose of training, retraining and advanced training is to bring theoretical knowledge as close as possible to practical activities, to articulate future vision of modern crime, to form the ability to operate quantitative and qualitative characteristics of crime, to organize and conduct activities for crime detection and crime prevention, as well as to ensure close cooperation with law enforcement agencies based on the use of general scientific methods of studying certain types of criminal behavior, the identity of the offender, general and individual forecasting, etc.

\section{Conclusion}

Analyzed the views of different authors, international experience and taking into account our own opinion, we consider that it is appropriate to establish an age limit for private detectives (at least 25 years), the relevant level of professional experience (at least 3 years in law enforcement agencies of Ukraine after obtaining higher legal education) and corresponding life experience.

Professional development of of private detectives should be carried out in the system of higher educational institutions with specific conditions of study, as training in a private educational institution is clearly insufficient. Training programs for future private detectives should provide in-depth study of relevant legal disciplines and special courses; in doing so, such programs should be provided only by scientific and pedagogical staff with a sufficient professional level in the corresponding areas.

Special training for private detectives is a kind of professional specialization for persons who already have higher legal education, but do not have three years of practical experience in the pre-trial investigation or operational units.

Ultimately, it should be noted that professional private detectives will always be in demand by society. Therefore, international experience will be helpful in forming a civilized market of detective services in Ukraine. 


\section{Bibliographic References}

ACT OF THE PARLIAMENT OF THE UNITED KINGDOM. 2002. The Police Reform Act of July 24 c. 30. Available online. In: https://www.legislation. gov.uk/ukpga/2002/30/contents. Consultation date: 19/09/2019.

BEZZUB, Iryna. 2017. "Private detective activity: Ukrainian realities and foreign experience" In: Social Communication Research Center. Available online. In: http://nbuviap.gov.ua/index.php?option=com_content\&v iew=article\&id=2930:privatna-detektivna-diyalnist-ukrajinski-realijita-zarubizhnij-dosvid\&catid=8\&Itemid=350. Consultation date: 19/09/2019.

BUGAYCHUK, Kostiantyn. 2016. "Institution of Private Detectives Abroad: Comparative Legal Analysis" In: Law and Security. No. 1, pp. 7 - 12.

FEDERAL SERVICE OF THE TROOPS OF THE NATIONAL GUARD OF THE RUSSIAN FEDERATION. 2019. On the approval of standard vocational training programs for private detectives of February 06 no. 33. Available online. In: http://docs.cntd.ru/document/552443267. Consultation date: $21 / 09 / 2019$.

KALENYAK, Vitalii. 2007. "Private security activities: foreign experience and the possibility of its use in Ukraine" In: Journal-Catalogue "Personnel". No. 5. Available online. In: http://personal.in.ua/article.php?ida=504. Consultation date: 21/09/2019.

KOBELETSKYI, Andrii. 2013. Current state and prospects of development of educational programs in the area of security. Available online. In: http://eprints.kname.edu.ua/38610/1/79-82.pdf. Consultation date: 19/09/2019.

KYSLYI Anatolii, PYSMENNA, Mariia, KOLOMOIETS, Oleksandr, VOLOBUIEVA, Olena, DAVYDENKO, Valerii. 2020. "Educational processes of training, retraining and advanced training of private detectives in Ukraine" In: Cuestiones Politicas, Vol. 38, No. 66, pp. 421 - 435, doi: https://doi.org/10.46398/cuestpol.38e.28 https:// produccioncientificaluz.org/index.php/cuestiones/article/view/34336

LA ASOCIACIÓN PROFESIONAL DE DETECTIVES PRIVADOS DE ESPAÑA. 2010. Côdigo Deontolôgico. Available online. In: http://www.apdpe.es/ codigo-deontologico. Consultation date: 29/09/2019.

LAW OF THE REPUBLIC OF MOLDOVA. 2003. On the private detective and security activities of July, 04 no. 283. Available online. In: http:// 
lex.justice.md/document_rus.php?id=DDBAo9C7:96oFB451. Consultation date: 05/09/2019.

MATIUKHINA, Nataliia. 2001. Police of Great Britain: modern tendencies of development and management: monograph. Charkiv, Ukraine. Consum.

MATIUKHINA, Nataliia. 2013. US private security sector: ways of development and realities of the present: monograph. Charkiv, Ukraine. Yurait.

MUSIENKO, Serhiei. 1996. Investigators and private detectives: the defenders of rights, property and life. Literature. Minsk, Belarus.

OFFICIALWEB-SITEOFTHEASSOCIATIONOF BRITISH INVESTIGATORS. 2020. Become a Private Investigator. Available online. In: https://www. theabi.org.uk/become-an-investigator. Consultation date: 05/09/2019.

PAVLENKO, Serhii; SEVRUK, Volodymyr; KOBKO, Yevhen. 2017. "Training police offuicers in the conditions of reforming the system of education of the Ministry of Internal Affairs of Ukraine in accordance with European standards" In: Science and Education. Vol. 164 No. 6, pp. 142 - 150.

PIDYUKOV, Petro. 2016. "Problems of legalization of private detective activity in Ukraine and the beginning of special training of its subjects" In: Legal Journal of the National Academy of Internal Affairs. Vol. 12, No. 2, pp. $165-177$.

SACHAVO, Andrii. 2006. Administrative and legal bases of activity of private security structures and their interaction with internal affairs agencies of Ukraine: monograph. Kyiv, Ukraine. Naukovyi svit.

VOLYNSKA, Alina. 2016. "Providing detective services according to the legislation of foreign countries: positive experience of civil law regulation" In: Scientific Bulletin of Uzhhorod National University. Vol. 39, No. 1, pp. 41-46.

YURKO, Serhii. 2017. Non-state security and law enforcement activities in Ukraine. PhD dissertation. National University "Odesa Law Academy". Odesa, Ukraine. 

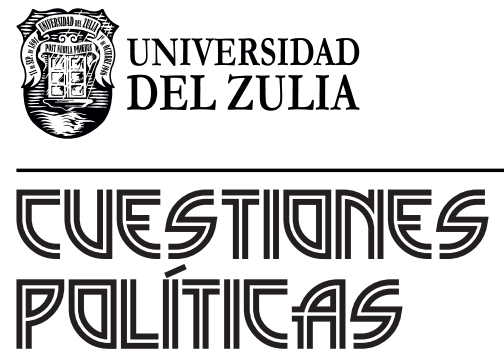

Vol.38 NEspecial

Esta revista fue editada en formato digital y publicada en diciembre de 2020, por el Fondo Editorial Serbiluz, Universidad del Zulia. Maracaibo-Venezuela 